\title{
Reply to
}

DOI:

10.1016/j.ejso.2016.05.034

10.1016/j.ejso.2016.05.034

\section{Document Version}

Accepted author manuscript

Link to publication record in Manchester Research Explorer

\section{Citation for published version (APA):}

Northwest Breast Surgical Research Collaborative (2016). Reply to: Letter Infection prevention in breast implant surgery - A review of the surgical evidence, guidelines and a checklist. European Journal of Surgical Oncology, 42(8), 1248. https://doi.org/10.1016/j.ejso.2016.05.034, https://doi.org/10.1016/j.ejso.2016.05.034

\section{Published in:}

European Journal of Surgical Oncology

\section{Citing this paper}

Please note that where the full-text provided on Manchester Research Explorer is the Author Accepted Manuscript or Proof version this may differ from the final Published version. If citing, it is advised that you check and use the publisher's definitive version.

\section{General rights}

Copyright and moral rights for the publications made accessible in the Research Explorer are retained by the authors and/or other copyright owners and it is a condition of accessing publications that users recognise and abide by the legal requirements associated with these rights.

\section{Takedown policy}

If you believe that this document breaches copyright please refer to the University of Manchester's Takedown Procedures [http://man.ac.uk/04Y6Bo] or contact uml.scholarlycommunications@manchester.ac.uk providing relevant details, so we can investigate your claim.

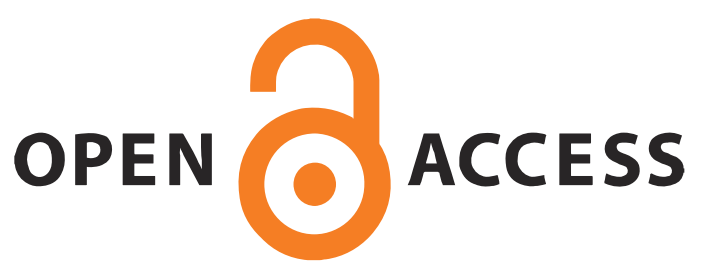




\section{Correspondence}

\section{Reply to: Letter Infection prevention in breast implant surgery - A review of the surgical evidence, guidelines and a checklist}

\section{Dear Editor}

We would like to thank the authors for their response to our review article. They correctly highlight that our recommendation with regards to antibiotic use in breast reconstruction is not supported by Level 1 evidence. Furthermore, we entirely agree regarding the risks of resistance and C.diff colitis when antibiotics are inappropriately prescribed. Our recommendation is however based on the best evidence available to us.

As there is already Level 1 evidence for prophylactic antibiotics reducing surgical site infection in patients having breast cancer surgery without reconstruction, ${ }^{1}$ we would emphasise the need for data specifically in those patients who are having reconstructive surgery. This is particularly important for implant-based reconstructions because they account for the majority of immediate breast reconstructions, ${ }^{2}$ and morbidity from infection in this setting is high.

The proposed audit is laudable, however such an endeavor should be designed in the context of the ongoing national iBRA study, ${ }^{3}$ a UK based audit of implant-based immediate breast reconstruction. Here, data on antibiotic use, infection rates and implant loss are being prospectively collected, with 1800 patients enrolled to date.

\section{Conflict of interest statement}

We have read and understood EJSO policy on declaration of interests. We declare that we have no competing interests.

\section{References}

1. Jones DJ, Bunn F, Bell-Syer SV. Prophylactic antibiotics to prevent surgical site infection after breast cancer surgery. Cochrane Database Syst Rev 2014;(3):CD005360.

2. Leff DR, Bottle A, Mayer E, et al. Trends in immediate postmastectomy breast reconstruction in the United Kingdom. Plast Reconstr Surg Glob Open 2015:3(9):e507.

3. iBRA Study Bristol. Available from: http://ibrastudy.com 2015
A.R. Topps ${ }^{1}$
S.P. Barr*,1
N.L.P. Barnes
C.C. Kirwan

On behalf of the Northwest Breast Surgical Research

Collaborative $^{2}$

The North West Breast Research Collaborative, United Kingdom

*Corresponding author. c/o The Nightingale Centre, University Hospital of South Manchester, Southmoor Road, Wythenshawe, M23 9LT, United Kingdom. Tel.: +44 (0) 1612914437; fax: +44 (0)1612914435. E-mail address: simon.barr@manchester.ac.uk (S.P. Barr)

Accepted 29 May 2016

DOI of original article: http://dx.doi.org/10.1016/j.ejso.2016.05.033

1 S.P. Barr and A.R. Topps are co-first authors.

2 http://nwresearch.org/breast-subgroup/. 